\title{
PERFIL DOS EGRESSOS DE UM PROGRAMA DE PÓS- GRADUAÇÃO DE GESTORES EM SAÚDE
}

Hangai, RK' | Ajimura, FY² | Silva, AC | Camargo, PCS'| Mota NVVP' 1: Corpo Técnico PROAHSA; 2: Diretor PROAHSA

\section{INTRODUÇÃO}

Instituições de saúde são consideradas complexas devido a coexistência de inúmeros processos assistenciais e administrativos, diversas linhas de produção simultâneas e uma fragmentação da decisão assistencial por uma equipe multidisciplinar com elevado grau de autonomia. O número de publicações sobre lideranças na saúde têm aumentado, enfatizando o desafio de preparar profissionais para assumirem as responsabilidades do cargo que irão ocupar. Entender a trajetória profissional dos egressos de um programa voltado para formação de gestores da saúde possibilita reflexão sobre a estrutura curricular existente, assim como identificar se o egresso desenvolveu habilidades e competências que favoreceram a entrada no mercado de trabalho.

\section{OBJETIVO}

Conhecer a trajetória profissional dos egressos de um programa de pós-graduação para formação de gestores em saúde situado no município de São Paulo.

\section{METODOLOGIA}

Estudo transversal descritivo utilizando questionário com questões fechadas e de múltipla escolha enviado anonimamente através de e-mail a todos os alunos formados pelo programa entre 2012 e 2017.

\section{RESULTADOS}

Dos 38 questionários enviados, houve retorno de 24 alunos $(63,2 \%)$ com predomínio do gênero masculino $(54,2 \%)$ e média de 31 anos. Cerca de $54,2 \%$ são aprimorandos e $45,8 \%$ médicos, sendo a idade média dos médicos mais elevada (33 vs 29 anos). O local mais frequente de trabalho foi 0 Hospital (45,8\%), seguido pelos Planos de Saúde $(18,2 \%)$ e Consultorias (13,6\%). As Instituições Privadas predominaram (68,18\%) frente às Públicas (31,82\%). O cargo de Gerente foi o mais frequente (36,4\%), seguido do Analista (18,2\%), Coordenador $(13,6 \%)$ e Assistente de Diretoria (13,6\%). Observou-se um predomínio dos médicos nos cargos de Diretoria, Gerência e Coordenadores $(66,7 \%$ vs $33,3 \%)$.

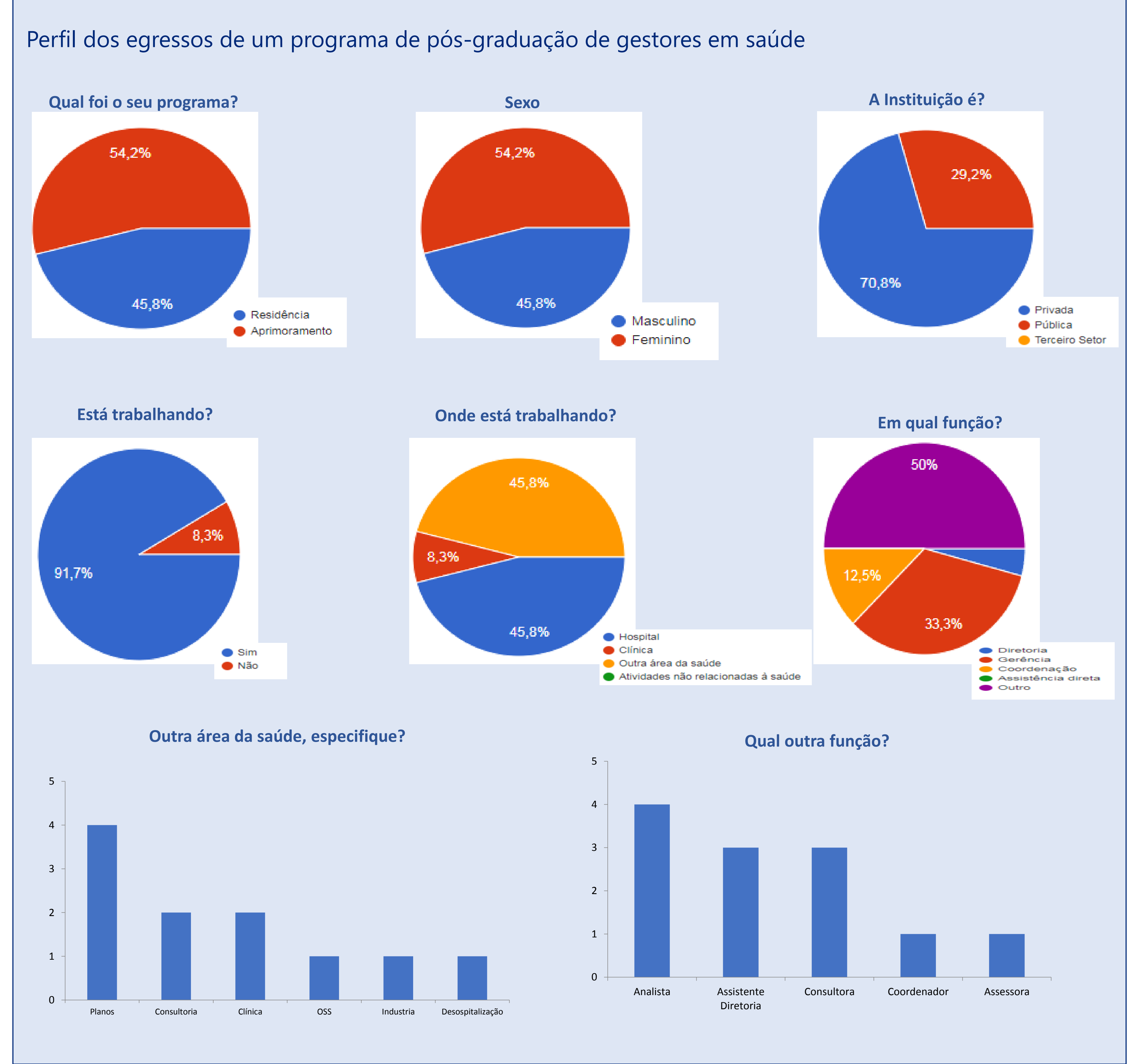

\section{CONCLUSÃO}

O programa inseriu no mercado mais de $90 \%$ dos egressos em áreas de gestão da saúde, atendendo às demandas. O modelo, baseado na capacitação teórica e no aprendizado pela experiência prática em diferentes locais de estágios realizando projetos em instituições públicas e privadas dos diversos players da saúde, possibilita desenvolver habilidade e competências que favoreçam a entrada no mercado de trabalho. 